ANNA MORACZEWSKA

Uniwersytet Marii Curie-Skłodowskiej

DOI : $10.14746 /$ rie.2017.11.3

\title{
Hybrydowość granic Unii Europejskiej w środowisku międzynarodowym
}

\begin{abstract}
Wstęp
Granice Unii Europejskiej (UE) są treścią wielu dokumentów na poziomie prawa wspólnotowego, umów międzynarodowych i prawa krajowego oraz przedmiotem ogromnej liczby analiz i badań naukowych. Pozostają jednym z bardziej uregulowanych elementów systemu Unii, a ewolucja owych regulacji odzwierciedla aktualne priorytety i wyzwania, wobec których stawały i stają państwa członkowskie oraz sama UE. Właściwie już u podstaw ustalania zasad działania granic późniejszej Unii - Umową z Schengen z 1985 r. - wychodziły one poza ich tradycyjną formułę, obowiązującą w ówczesnym zimnowojennym środowisku międzynarodowym. Unia Europejska stała się prekursorem budowania bezpieczeństwa państw opartego nie na wznoszeniu barier i zaostrzaniu zasad przekraczania granic, ale na znoszeniu ich fizycznej formy i kontroli granicznej.

Celem artykułu jest przedstawienie podejścia do analizy obiektu - granic Unii Europejskiej - przez pryzmat ich cech, określonych jako hybrydowe. Sekcja pierwsza artykułu definiuje pojęcie granic państwa i koncepcję hybrydy, a druga uzasadnienie postrzegania granic UE jako formy hybrydowej. Analiza bazuje na wyznacznikach środowiska późnowestfalskiego i transnarodowym paradygmacie stosunków międzynarodowych (SM).
\end{abstract}

\section{Granica państwa w stosunkach międzynarodowych}

Cechy współczesnego środowiska międzynarodowego przekształciły postrzeganie granicy państwa, jako jedynie bytu terytorialnego, ,rozpraszając” jej funkcje w przestrzeni międzynarodowej. Podobnie jednak, jak same SM, w wielu wymiarach zachowała status quo. Na przełomie XX i XXI w. pojawiało się wiele koncepcji o równolegle przebiegających procesach asymetrycznych, przejawiających się znoszeniem oraz przywracaniem granic (de-bordering i re-bordering) i wpisujących się w zjawiska deterytorializacji i re-terytorializacji, różnego rodzaju działań i oddziaływań (Moraczewska, 2008a, s. 44-47). Współczesny filozof francuski - Étienne Balibar pod koniec lat dziewięćdziesiątych XX w. użył określenia „niezdecydowanych”/,niezdecydowania” granic [vacillation of borders], których cechą jest występowanie w nich sprzeczności (Balibar, 1998, s. 216-263).

Jednym z przedmiotów badań w SM jest porządek międzynarodowy, który wyznacza zasady funkcjonowania podmiotów w środowisku, a jednocześnie poszukiwanie 
w nim pewnych prawidłowości pozwala na głębszą analizę i wyjaśnianie rzeczywistości międzynarodowej. Taki system jest zazwyczaj ustalany/tworzy się po okresie długotrwałej turbulencji, jak wojny, konflikty i ma na celu porządkowanie przestrzeni międzynarodowej przez ustalanie nowych zasad czy norm działania podmiotów SM (nie zawsze i nie we wszystkich wymiarach musi być sterowany). Przykładami są porządek westfalski, ustalony w roku 1648 po wojnie trzydziestoletniej, czy system zimnowojenny wyłoniony w wyniku trzech konferencji w Teheranie, Poczdamie i Jałcie po II wojnie światowej. Upadek tego drugiego na początku lat dziewięćdziesiątych XX wieku przyniósł fundamentalne zmiany $\mathrm{w}$ środowisku międzynarodowym: m.in. powstanie nowych państw w nowych granicach, przekształcenie obowiązujących ponad 40 lat form relacji, rozwinął nowe formy oddziaływań, jednak nie przyjął formalnej postaci umowy czy traktatu międzynarodowego. Można raczej stwierdzić, że „,nowy ład", nawiązujący do systemu westfalskiego, jest wynikiem wielu umów i konwencji rozłożonych w czasie i skutkujących powstaniem współzależności liberalnych między państwami oraz pojawiania się coraz większej liczby podmiotów pozapaństwowych i ich wzajemnych relacji. Nie zrywa całkowicie z elementami triady westfalskiej: władza-suwerenność-terytorialność, ale zmienia ich interpretację na bardziej płynną. Podobnie więc jak ,niezdecydowane granice” cechuje go ciągłość i zmienność. Określany jest czasami jako hybryda „westfalskiej” ciagłości i „powestfalskiej” zmiany (Pietraś, Marzęda, 2008, s. 9).

Y. Lapid twierdzi, że granice są ściśle związane z pojęciem porządku międzynarodowego, a wszelkie działania dotyczące ich przesunięć, konstrukcji czy zasad przekraczania ,niosą za sobą wielkiej wagi konsekwencje dla politycznego porządku na wszystkich poziomach analizy" (Lapid, 2001, s. 7). Są więc kluczowym elementem konstrukcji oraz dekonstrukcji państwa i budowania porządku przestrzeni międzynarodowej.

W literaturze można spotkać również określenie bordering i bordering practices. Trudno jest uchwycić sens tego pojęcia w języku polskim i próba tłumaczenia na np. „graniczenie” czy „metody, praktyki procesu graniczenia” nie brzmi stylistycznie poprawnie i nie oddaje sensu jego znaczenia w języku angielskim. Określenie to odnosi się do wzrostu metod i instrumentów kontroli przepływu, głównie osób, przez granice państwa oraz zarządzania tą granica, które wnoszą poza-terytorialny wymiar granicy. W dokumentach Ministerstwa Spraw Wewnętrznych Wielkiej Brytanii jest ono określone jako „koncepcja eksportowania granic po całym świecie” (Home Office UK, 2006, s. 7). Bordering practices obejmują m.in. programy e-borders, analizy ryzyka związanego z przekraczaniem granic czy działania proaktywne wobec osób, które dopiero zamierzają przekroczyć granicę danego państwa (Vaughan-Williams, 2012, s. 17-24). Z punktu widzenia stosunków międzynarodowych określenie to precyzyjniej odzwierciedla istotę współczesnych granic, wychodzących poza ramy formalnoprawne na poziomie jednego państwa i samej demarkacji oraz delimitacji granicy, ale ukierunkowanych na współpracę z innymi podmiotami państwowymi w celu zwiększenia wzajemnego bezpieczeństwa wewnętrznego każdego z nich.

Funkcje granic uległy przekształceniom $\mathrm{w}$ wyniku pojawiania się podmiotów pozapaństwowych, z których wiele działa ponad granicami czy też w poprzek granic. W ten sposób zaciera się ostra linia dzieląca środowisko wewnętrzne państwa od śro- 
dowiska zewnętrznego najwyraźniej widoczne w stosunkach gospodarczych (Moraczewska, 2008b, 366).

\section{Hybryda i procesy hybrydyzacji w stosunkach międzynarodowych}

Próbując zidentyfikować właściwości jakiegoś systemu, należałoby najpierw zbadać i opisać właściwości jego elementów. Nie zawsze jednak kompilacja cech tych elementów pozwala na uchwycenie rzeczywistej istoty całego systemu. Keneth. N. Waltz, już w latach siedemdziesiątych XX w. (Waltz, 1979), krytykował redukowanie teorii systemów do analizy tworzących go elementów. Istotne są natomiast relacje między nimi oraz zmiana tych relacji. W wielu przypadkach owa zmiana jest bardziej znacząca, aniżeli dotychczasowe powiązania, ponieważ jej analiza pozwala na oderwanie się od tradycyjnie rozumianych związków między określonymi elementami (np. relacja granic zewnętrznych i wewnętrznych państwa). Jeżeli dodatkowo cechy poszczególnych elementów komplikują się i wykraczają poza ich wcześniej rozpoznane funkcje, wówczas system zaczyna działać w sposób nieschematyczny i nabiera właściwych tylko sobie cech.

A. Bernhard, analizując hybrydowość w kontekście kulturowym i procesie budowania pokoju, wyróżniła cztery jej rodzaje: 1) jako wynik stosunków opartych na dialogu; 2) jako wynik strategii odrzucenia i akceptacji; 3) jako proces adaptacji zwiększający szanse ustanowienia zrównoważonego i trwałego pokoju oraz 4) jako punkt odniesienia do oceny legitymizacji lub zakresu współtworzenia pokoju przez różnych aktorów (Bernhard, 2013, s. 13). Pierwsze i trzecie ujęcie wydaje się być adekwatne w analizie hybrydowości granic Unii Europejskiej. Bernhard uważa, że stosunki oparte na dialogu między podmiotami prowadzą do wyłonienia hybrydowych rozwiązań, z tego względu, że zaangażowane w dialog strony wzajemnie otwierają się na nowe podejście do danego zjawiska prezentowane przez drugą stronę i w ten sposób wychodzą poza jedynie własne wzory postrzegania rzeczywistości. W takim ujęciu hybrydyzacja jest skompilowanym efektem procesu wzajemnej wymiany myśli, pomysłów i adaptacji zachowań kilku aktorów do innych potrzeb, norm oraz odmiennych punktów widzenia i interesów. Jest niejako ich mieszaniną ${ }^{1}$. Proces hybrydyzacji polega więc na odchodzeniu od utartych praktyk i/lub ich rekombinacji.

W materiałach naukowych z zakresu stosunków międzynarodowych, a także analizach publicystycznych popularności nabrało określenie „hybrydowość”, najczęściej występujące w powiązaniach: ,zagrożenia hybrydowe” czy „wojny hybrydowe"2. Pojęcie hybryda nawiązuje do mitologii greckiej i postaci łączących w sobie cechy zewnętrzne i wewnętrzne różnych zwierząt, bogów i ludzi, ludzi i zwierząt (były nimi np. chimera, cerber, sfinks). Miały one odzwierciedlenie w ich właściwościach, co przekładało się na mniej lub bardziej niszczycielskie działania tych istot. Stąd hybry-

${ }^{1}$ Oczywiście nie można zakładać, że efektem każdego dialogu będzie hybrydowe rozwiązanie. Można jedynie przyjąć, że w jego wyniku podmioty uczestniczące odchodzą od dotychczasowych schematów działań i zachowań, tworząc nową jakość.

${ }^{2}$ Zjawisku hybrydowości poświęcony jest jeden z numerów czasopisma „Sprawy Międzynarodowe”, patrz szerzej: „Sprawy Międzynarodowe” 2015, nr 2, PISM. 
da łączy w sobie nieschematyczną strukturę z nietypowymi instrumentami i taktykami działania. F. Hoffman twierdzi, że współczesne zagrożenia i wojny hybrydowe to zjawiska, które łączą gamę różnych rodzajów działań i taktyk wojennych, w tym środków konwencjonalnych i niekonwencjonalnych, stałych i tymczasowych formacji zbrojnych, aktów terrorystycznych oraz przestępczości zorganizowanej. Wojny hybrydowe mogą być prowadzone przez podmioty państwowe i niepaństwowe, a działania w dużej mierze mają na celu zaskoczenie wroga i wykorzystanie jego słabych punktów (Hoffman, 2007, s. 14). Tym samym hybrydowe konflikty komplikują proces decyzyjny i spowalniają koordynację skutecznych reakcji. Nieschematyczność zjawisk hybrydowych powoduje, że nie mieszczą się one w ramach dotychczas panujących zasad porządku międzynarodowego i wymagają kreatywnych działań antycypacyjnych w celu uniknięcia zaskoczenia i zaniechania lub redukcji strat. Cyberataki są przedstawiane jako klasyczny przykład takich zagrożeń ze względu na trudną identyfikację ich pochodzenia oraz branie na cel istotnych elementów systemu.

Zagrożenia hybrydowe podważają istotność granic państwa w pewnym sensie, gdyż najczęściej nie stanowią one dla nich znaczącej bariery. Jednocześnie wymagają reakcji wychodzących poza te granice. J. J. Andersson i T. Tardy, analizując działania operacyjne Unii Europejskiej wobec zagrożeń hybrydowych, uznali, że potrzebują one po pierwsze, wyraźnego określenia obowiązków podmiotów na poziomie wspólnotowym oraz państwowym i po drugie, jednoczesnego wykorzystania oraz zastosowania instrumentów i działań państw członkowskich, instrumentów bezpieczeństwa wewnętrznego UE powołanych w ramach Przestrzeni wolności, bezpieczeństwa i sprawiedliwości, a także narzędzi i działań zabezpieczających środowisko zewnętrzne UE (np. w ramach operacji WPBiO) oraz NATO. (Andersson, Tardy, 2015). Kluczowego znaczenia nabierają tu systemy wywiadowcze i nadzorujące, monitorowanie, gromadzenie i przetwarzanie informacji, a także ich wymiana w celu zachowania gotowości wobec zagrożenia lub jego zaniechania.

Struktury „hybrydowe” czy „procesy hybrydyzacji” nie przyjmują formy stałej - niezmiennej. Ulegają ciagłym przekształceniom, mniej lub bardziej dynamicznym i przebiegają $\mathrm{w}$ różnych kierunkach i na różnych poziomach. Ma to szczególne znaczenie w przypadku zagrożeń hybrydowych, których istotnym atrybutem, jak wspominano powyżej, jest efekt zaskoczenia i niepewność. Udział w stosunkach międzynarodowych podmiotów państwowych i pozapaństwowych, formalnych i nieformalnych, zorganizowanych i rozproszonych, jawnych i niejawnych, narodowych i ponadnarodowych komplikuje relacje między nimi i wymusza kreatywność w doborze instrumentów oddziaływania.

\section{Hybrydyzacja granic Unii Europejskiej}

Występowanie sprzecznych cech współczesnych granic, określone przez E. Balibara jako ich niezdecydowanie [vacillation of borders], wpasowuje się w pojęcie „chimeryczności" granic. Chimera natomiast była rodzajem mitologicznej hybrydy, której współczesne znaczenie określa właśnie niezdecydowanie, kapryśność, zmienność (Stownik...). Balibar używa tego pojęcia w odniesieniu do wielu granic w przestrzeni 
i czasie, z których jedne są bardziej wrażliwe na zmiany środowiskowe, a inne mniej. W niniejszym artykule zakłada się, że granice Unii Europejskiej mają formę hybrydową, ale nie tyle opartą na „niezdecydowaniu”, co na zmienności i asymetryczności w wymiarze terytorialnym i instytucjonalno-prawnym. Zasady ich funkcjonowania wychodzą poza ramy systemu westfalskiego, ale nie odrzucają go całkowicie i nie mają dotychczas żadnego odpowiednika w środowisku międzynarodowym. Reprezentują cechy, które są sprzeczne wobec siebie, ale nie wykluczają się wzajemnie, gdy działają razem.

W oparciu o wcześniejszą analizę zjawiska i procesu hybrydyzacji można wyszczególnić cztery wymiary hybrydowości granic Unii Europejskiej: 1) hybrydowość funkcjonowania granic jako elementów systemu UE; 2) hybrydowość granic UE jako efekt dialogu między państwami członkowskimi; 3) hybrydowość granic UE jako efekt ich adaptacji do wyzwań środowiska międzynarodowego oraz 4) hybrydowość zarządzania granicami UE.

\section{Hybrydowość funkcjonowania granic jako elementów systemu UE}

Sama Unia Europejska jest przykładem struktury hybrydowej ${ }^{3}$ i wiele elementów, które ją konstytuują prezentuje właściwości typowe i nieschematyczne. Granice UE wpasowują się w cechy systemu późnowestfalskiego, wyznaczając zakres terytorialny i prawny narodowych państw członkowskich oraz zasięg przestrzenno-terytorialny i wspólnotowy całego obszaru Unii. Nie ma ona jednak samodzielnie charakteru terytorialnego, a jedynie przez państwa terytorialne, które wnoszą swoje granice do obszaru wspólnotowego. Zdefiniowanie granic państw członkowskich (nie-peryferyjnych), jako granic wewnętrznych zmieniło ich wymiar w polityce zagranicznej państwa. Natomiast wprowadzenie pojęcia granic zewnętrznych nałożyło na państwa peryferyjne dodatkową granicę - między obszarem Unii Europejskiej a państwami trzecimi (por. Rozporządzenie PE i Rady UE 2016/399 z 9 marca 2016 r., art. 2 p. 1, 2). Nie naruszając integralności i nienaruszalności terytorialnej państwa członkowskiego, UE pozbawiła go (z wyjątkami) sprawowania kontroli na własnych granicach, przynależnych do wnętrza UE. Taka formuła zdewaluowała znaczenie granicy dla państw leżących wewnątrz obszaru Unii, wzmacniając jednocześnie jej rolę dla państw flankowych. S. Carrera i in. uważają, że Kodeks graniczny Schengen oraz ustandaryzowanie ogólnych zasad funkcjonowania granic państw UE,,(o)graniczyły [...] pole manewru i suwerenności państw członkowskich UE w zakresie zarządzania mobilnością ludzką i granicami" (Carrera i in., 2012, s. 59). Z drugiej strony pozostawiono państwom możliwość przywracania kontroli na swoich granicach wewnętrznych „w przypadku, gdy poważne zagrożenie porządku publicznego lub bezpieczeństwa wewnętrznego wymaga natychmiastowego działania” (Rozporządzenie PE i Rady UE 2016/399

${ }^{3}$ Hybrydowość Unii Europejskiej widoczna jest między innymi w jej ustroju, suwerennych państw członkowskich i ponadnarodowej struktury UE, połączenia cech organizacji międzypaństwowej i międzynarodowej, nachodzących na siebie kompetencji uczestników Unii, zacierania podziałów między środowiskiem wewnętrznym i zewnętrznym państw członkowskich (szerzej: Słomczyńska, 2008, s. 423-431). 
z 9 marca 2016 r., s. L 77/3 pkt 23). Hybrydowość granic Unii w ujęciu pierwszym, przejawia się również w zachowaniu przez niektóre państwa członkowskie „reliktów terytorialnych" z okresu kolonializmu. Należą tu wyspy m.in. Wyspy Kanaryjskie czy Lampedusa, hiszpańskie enklawy Ceuta i Mellila leżące wewnątrz Maroka czy obszary zamorskie, jak francuska Gujana. Ich terytoria wychodzą poza kontynentalny obszar Unii Europejskiej, a tym samym poza zasady dotyczące kontroli granic Unii. Podsumowując należy stwierdzić, że granice państw członkowskich UE zachowały swój wymiar terytorialny, ale zmieniony został ich wymiar funkcjonalny. Zmieniły się relacje między granicą wewnętrzną a zewnętrzną w tradycyjnym ich rozumieniu. Granice państw członkowskich UE występują równolegle (nie oznacza razem), jako zewnętrzne oraz wewnętrzne i wzajemnie warunkują swoje funkcjonowanie. Granice zewnętrzne UE tworzą międzynarodowy porządek przestrzenny, a granice wewnętrzne de-konstruują narodowy porządek terytorialny.

\section{Hybrydowość granic UE jako efekt dialogu między państwami czlonkowskimi}

Odnosząc granice Unii Europejskiej do koncepcji A. Bernhard o powstawaniu hybryd w wyniku podjęcia dialogu między podmiotami, należy sięgnąc do genezy idei integracji gospodarczej na obszarze współczesnej Unii. Dialog i współpraca państw europejskich, po drugiej wojnie światowej, miały przeciwdziałać przyszłym konfliktom terytorialnym, wywołać efekt synergii ze współpracy i wzajemnie udzielanych preferencji, a tym samym zapobiec wyniszczającym wojnom w Europie i naruszaniu granic, terytoriów państw. Formalnie idea została potwierdzona w 1985 r. przez podpisanie Układu z Schengen o stopniowym znoszeniu kontroli na wspólnych granicach umawiających się stron, którego wprowadzanie w życie było nie tyle aktem co procesem przebiegającym wraz z rozszerzeniem i pogłębianiem Unii. Powołaniem strefy Schengen, ze swobodą przekraczania granic wewnętrznych oraz włączeniem acquis Schengen do prawa wspólnotowego traktatem amsterdamskim ujednolicono podstawy prawne zasad przekraczania granic zewnętrznych i wewnętrznych.

Dialog podjęty w celu zaniechania konfliktom granicznym między państwami europejskimi doprowadził w efekcie do „ekstremalnego” przekształcenia linii dzielących te państwa na obszary łączące je. Likwidacja infrastruktury i kontroli granicznej spowodowała zatarcie fizycznych podziałów, a terytorium Unii zaczęło odzwierciedlać ideę obszaru bez granic. Dialog doprowadził do dobrowolnego zniesienia kontroli na granicach wewnętrznych, a wszelkie działania związane z jej przywracaniem wymagają również uzgodnień wszystkich stron na poziomie międzyrządowym i ponadnarodowym. Dialog stał się afirmacją wspólnej potrzeby rozwoju gospodarczego i wzajemnego zaufania, ale uwzględniał też indywidualne interesy czy stanowiska państw, jak chociażby Wielkiej Brytanii, dla której swoboda przemieszczania się nie była równoznaczna ze zniesieniem kontroli na jej granicach. $Z$ jednej strony mamy więc odejście od partykularnych interesów państwa członkowskiego, z drugiej zrozumienie odmiennego stanowiska niektórych państw w kwestii ich granic. 


\section{Hybrydowość granic UE jako efekt ich adaptacji do wyzwań środowiska międzynarodowego}

Procesom adaptacji towarzyszą jednocześnie zmiana i trwałość. Zmiana ma zapewnić przetrwanie oraz przywracanie naruszonej, w wyniku określonych bodźców, homeostazy. Ziemowit J. Pietras wyróżnił sześć rodzajów adaptacji państwa: trzy wg aktywności systemu - aktywną, kreatyną i pasywna, oraz trzy wg kryterium czasu - retroaktywną, reaktywną i antycypacyjną (Pietraś, 1990, s. 4-18). Adaptacja kreatywna, choć nie jako jedyna, odzwierciedla procesy hybrydyzacji granic Unii Europejskiej. Podmiot adaptujący się zgodnie z tym rodzajem, uwzględniania bodźce pochodzące ze środowisk wewnętrznego i zewnętrznego, na które reaguje w sposób kreatywny. Oznacza to, że filtruje je i przyjmuje te, które uzna za niezbędne dla zachowania własnej równowagi, bezpieczeństwa, a jednocześnie rozwoju.

Po podpisaniu w 1985 roku Traktatu z Schengen Wspólnota Europejska/Unia Europejska zmieniała sześciokrotnie przebieg swoich granic - w 1986 r. włączając terytorium Hiszpanii i Portugalii, w 1990 r. - byłą Niemiecką Republikę Demokratyczną (w wyniku integracji Niemiec), w 1995 r. Austrii, Finlandii, Szwecji, w 2004 r. Czech, Cypru, Estonii, Litwy, Łotwy, Malty, Polski, Słowacji, Słowenii i Węgier, w 2007 Bułgarii i Rumunii oraz w 2013 r. Chorwacji. Procesy rozszerzenia zwiększyły liczbę i długość granic wewnętrznych, a także w wymiarze geopolitycznym jakość granic zewnętrznych. Rozszerzenia, które dokonały się już w XXI w. (oraz włączenie byłej NRD), są przykładami adaptacji Unii Europejskiej do zmieniającego się środowiska zewnętrznego związanego z rozpadem ZSRR i upadkiem systemu bipolarnego. Strategia stabilizowania zagranicy przez udział, a następnie włączenie transformujących się systemowo państw sąsiednich do Unii i strefy Schengen była odpowiedzią na te zmiany, a jednocześnie działaniem zwiększającym rozwój rynku wewnętrznego UE (Moraczewska, 2015).

Hybrydowość granic UE, jako efekt ich adaptacji przejawia się też w niespójności przynależności państw członkowskich do strefy Schengen. Należą do niej jednocześnie państwa członkowskie i nieczłonkowskie Unii, nie biorą w niej udziału niektórzy członkowie UE oraz nie wszystkie państwa Unii mają zniesioną kontrolę na swoich granicach wewnętrznych. Pierwszy przypadek dotyczy członkostwa Norwegii, Islandii, Szwajcarii i Lichtensteinu w strefie Schengen, a nieuczestniczeniu w niej Irlandii, Wielkiej Brytanii (bez uwzględnienia Brexitu) i częściowo Danii. W drugim natomiast, w Bułgarii, Rumunii, Chorwacji oraz na Cyprze nie zniesiono kontroli na granicach wewnętrznych. Nie-paralelność dotyczyła również likwidacji kontroli na granicach lądowych i powietrznych państw strefy Schengen. Na „zniesienie granic" z państwami skandynawskimi spoza Unii wpływ miało m.in. przystąpienie Szwecji i Finlandii do UE, które jeszcze wcześniej funkcjonowały w ramach skandynawskiej unii paszportowej. Brak udziału Wielkiej Brytanii i Irlandii w strefie Schengen był możliwy jeszcze przed 1999 r., zanim traktatem amsterdamskim włączono dorobek Schengen do prawa wspólnotowego i wszystkie kolejne państwa nie miały tzw. możliwości opt-out. Pomimo jednak, że Bułgaria, Rumunia i Chorwacja należą formalnie do strefy Schengen są zobowiązane przeprowadzać kontrolę na granicach wewnętrznych (zazwyczaj wyrywkowo i ogólnie), gdyż zdaniem innych 
członków Unii Europejskiej nie spełniają w wystarczającym stopniu technicznych warunków kompensacyjnych lub innych.

Adaptacja dotyczy również zmian statusu prawnego dorobku Schengen, jego ciągłej weryfikacji i modyfikacji - wprowadzaniu w jego ramach nowych instrumentów jak kodeks graniczny Schengen, system informacyjny Schengen, wizowy system Schengen (Rozporządzenie Parlamentu Europejskiego i Rady (WE) nr 562/2006). Dodatkowo w związku z nowymi wyzwaniami, wobec których stawała Unia, jak przepływ i aktywność na obszarze UE zorganizowanych grup terrorystycznych oraz masowy napływ uchodźców i nielegalnych imigrantów, dokonano kilkukrotnej modyfikacji kodeksu, z których ostatnia miała miejsce w marcu 2016 r. (Rozporządzenie Parlamentu Europejskiego i Rady (UE) 2016/399).

Ciagłe wyzwania, wobec których staja poszczególne państwa członkowskie i obszar Unii Europejskiej zmusza ich do modyfikowania przepisów granicznych, ale bez zasadnego naruszania podstawowej idei, jaką jest swoboda przepływu przez granice. Ma więc miejsce ciagłość i zmiana wpasowane w rozszerzanie i pogłębianie obszaru „bez granic”.

\section{Hybrydowość zarzq̨dzania granicami UE}

Zarządzanie granicami Unii Europejskiej jest przykładem zarządzania wielopoziomowego łączącego kompetencje państw i instytucji ponadnarodowych. Wielopoziomowy system zarządzania zachował zasadę suwerenności państwa członkowskiego na jego terytorium i granicach, rozszerzył ich zadania i obowiąki w prawidłowym funkcjonowaniu rozległej przestrzeni wspólnotowej oraz skoordynował ich działania na poziomie ponadnarodowym. Nastapiło niejako odejście od koncentracji jedynie na państwie ograniczonym terytorialnie na rzecz identyfikacji wszystkich członków z przestrzenią wolności przemieszczania się i bezpieczeństwa granic zewnętrznych Unii. A. Siehr pisze o współczesnej formie zarządzania terytorialnego w Unii Europejskiej, jako territorial governance i powołuje się na treść Agendy Terytorialnej UE, która określa sposoby zarządzania przestrzeniami państw członkowskich oraz stanowi treść dotyczącą podziału ról i zakresu odpowiedzialności poszczególnych struktur na poziomie narodowym, subnarodowym i supranarodowym (Siehr, 2012, s. 143).

Efektywne zarządzanie bezpieczeństwem granic jest warunkiem funkcjonowania Obszaru Wolności, Bezpieczeństwa i Sprawiedliwości Unii Europejskiej ustanowionego Traktatem o Unii Europejskiej i Traktatem o Funkcjonowaniu Unii Europejskiej (TUE i TFUE, Dz. U. C 115 z 9.05.2008). Bezpieczeństwo granic Unii i obszaru wspólnotowego są oparte na dwóch zasadach: zasadzie solidarności w zapewnianiu bezpieczeństwa i zasadzie współzależności w zarządzaniu granicami zewnętrznymi. Jak można przeczytać w kodeksie granicznym Schengen „(k)ontrola graniczna leży w interesie nie tylko państwa członkowskiego, na którego granicach zewnętrznych jest ona dokonywana, ale i w interesie wszystkich państw członkowskich, które zniosły kontrolę graniczną na granicach wewnętrznych" (Rozporządzenie Parlamentu Europejskiego i Rady (UE) 2016/399, pkt 6, s. 2). Jednocześnie na państwach posiadających linię granicy zewnętrznej spoczywa wysoka odpowiedzialność za bezpieczeństwo 
wszystkich pozostałych państw Schengen. Natomiast współzależność w zarządzaniu granicami ma kształt sieci, na którą składają się narodowe i ponadnarodowe struktury instytucjonalne (m.in. Frontex, eu-LISA, ministerstwa i podlegające im krajowe oddziały straży/policji granicznej, oficerowie łącznikowi), działania operacyjne (np. pościgi transgraniczne, akcje ratunkowe RAPID), ujednolicone przepisy i instrumenty w zakresie przekraczania granic (np. polityka wizowa, azylowa, koncepcja inteligentnych granic, zautomatyzowane systemy kontroli granicznych ABC), bazy danych (SIS II, VIS, Eurodac) oraz techniczne i finansowe wsparcie na rzecz podnoszenia jakości ochrony granic. Dodatkowo w zarządzanie granicami UE są zaangażowane państwa trzecie (np. Ukraina i Turcja), które w pewnym sensie są niejako odpowiedzialne za bezpieczeństwo państw członkowskich UE. Mówi się tu o tzw. off-shoringu granic polegającym na wychodzeniu zarządzania tymi granicami poza terytorium, do których one przynależą. Celem jest stworzenie ,zewnętrznych linii obrony” mających na celu zatrzymanie zagrożeń zanim jeszcze dotrą do granic państwa, które stosuje tą strategię (Vaughan-Williams, 2012, s. 18-20).

Mieści się to we wcześniej wspominanej koncepcji bordering-u.

W zasadach funkcjonowania strefy Schengen można mówić o sprzeczności, jaka pojawia się między bezpieczeństwem a wolnością przemieszczania się. Państwa Unii Europejskiej z jednej strony mają prawo do przywracania kontroli na swoich granicach wewnętrznych, z drugiej są zobowiązane do zapewnienia swobody przepływu osób przez ich granice. Przywracanie kontroli przez niektóre z nich w 2014 i 2015 r. w wyniku przemieszczającej się fali uchodźców i nielegalnych imigrantów wywołało burzliwe dyskusje na poziomie instytucjonalnym UE. W efekcie rozbudowano przepisy dotyczące sytuacji i sposobów wprowadzenia kontroli na granicach wewnętrznych, w kodeksie granicznym Schengen oraz zmianę nazwy wraz z rozwojem kompetencji Frontexu. Dotychczasowa Agencja ds. Zarządzania Współpracą Operacyjną na Zewnętrznych Granicach Państw Członkowskich Unii Europejskiej otrzymała miano Europejskiej Agencji Straży Granicznej i Przybrzeżnej (Rozporządzenie Parlamentu Europejskiego i Rady (UE) 2016/1624 z 14 września 2016 r.). W wyniku tych zmian ustanowiono, że „,nowa” Agencja oraz organy krajowe państw członkowskich odpowiedzialne za zarządzanie granicami, w tym straże przybrzeżne, tworzą Europejską Straż Graniczną i Przybrzeżną (Rozporządzenie Parlamentu Europejskiego i Rady (UE) 2016/1624 z 14 września 2016 r., art. 3 pkt 1), a więc jednostkę o charakterze międzynarodowym, na której spoczywa odpowiedzialność za bezpieczeństwo granic zewnętrznych Unii, jakie dotychczas posiadali funkcjonariusze narodowych straży granicznych.

Przedstawione cztery formy hybrydowości granic UE wskazują wysoką złożoność samych granic Unii i procesu dochodzenia do niej. Wynika ona z zaangażowania kilku poziomów regulujących funkcjonowanie granic i wielu podmiotów uczestniczących w tym procesie, których liczne interakcje wpływają na nieschematyczność granic Unii. Nie można powiedzieć, że obrana na początku idea „luzowania” granic podąża tylko w tym kierunku, ale raczej hybrydowość granic jest wypadkową procesów terytorializacji granic państw i de-terytorializacji obszaru bez granic. Granice poszczególnych państw członkowskich jako elementy przestrzennego systemu Unii nie są podatne w równym stopniu na zachowania całego systemu (UE), stąd podlegają regulacjom wspólnotowym i indywidualnym interesom. 


\section{Wnioski}

UE przyczyniała się do jakościowej zmiany istoty granic państwowych w wymiarze międzynarodowym i odejścia od podstawowego zadania granicy tj. ograniczania, dzielenia na rzecz otwierania i swobody. Pod wpływem czynników egzogennych i endogennych jej granice są systematycznie definiowane na nowo w sensie terytorialnym i funkcjonalnym. Odzwierciedlają one hybrydową istotę samej Unii. Na podstawie przeprowadzonej analizy, można zestawić ich niespecyficzne cechy - zaliczone do hybrydowych:

- na obszarze Unii Europejskiej nastąpiła redefinicja wewnętrznego i zewnętrznego wymiaru granic państwa;

- granice zewnętrzne UE pozostają terytorialnie zdefiniowane, ale przestrzeń polityki dotyczącej granic wychodzi daleko poza to terytorium;

- są unikalnym bytem w kategorii prawa międzynarodowego (są przedmiotem polityk narodowych i ponadnarodowej);

- analiza przebiegu granic zewnętrznych wskazuje na ich niejednorodność i zmienność, typowość i wyjątkowość;

- są stabilne chociaż nie są trwałe;

- wyznaczają terytorium, przestrzenie i strefy, choć nie zawsze pokrywające się wzajemnie;

- bezpieczeństwo wewnętrzne odnoszące się tradycyjnie do terytorium w granicach państwa członkowskiego zawiera w sobie bezpieczeństwo poza jego granicami;

- są asymetryczne w zakresie ich przekraczania - umożliwiają swobodę dla jednych i blokują ich przekraczanie innym.

W związku z jakościową zmianą zagrożeń, ich oderwaniem od terytorium i wejściem w przestrzeń międzynarodową można zastanawiać się czy hybrydowość granic UE wzmacnia i broni Unię przed hybrydowymi zagrożeniami, czy skazuje ją na kryzysy. Doświadczenia z ostatnich lat (2013-2016), związane z eksodusem uchodźców i nielegalnych imigrantów oraz wzrostem ataków i zagrożeń terrorystycznych, przyczyniły się do większej konsolidacji zasad funkcjonowania granic Unii, jak również doprowadziły do tymczasowego kryzysu strefy Schengen. Wydaje się jednak, że hybrydowość pozwala na lepsze zidentyfikowanie nietypowości innych obiektów, w tym zagrożeń i ułatwia działania podejmowane wobec nich przy wykorzystaniu własnych nieschematycznych rozwiązań i instrumentów.

\section{Bibliografia}

Andersson J. J., Tardy T. (2015), Hybrid: what's in a name?, „Brief Issue”, nr 32, European Union Institute for Security Studies, http://www.iss.europa.eu/uploads/media/Brief_32_Hybrid_warfare.pdf, 2.11.2016.

Andreas P. (2000), Introduction: the wall after the wall, w: The wall around the west: State borders and immigration controls in North America and Europe, red. P. Andreas, T. Snyder, Lanham.

Balibar E. (1998), The borders of Europe, w: Cosmopolitics: Thinking and Feeling beyond the Nation, red. P. Cheah, B. Robbins, Minneapolis. 
Bernhard A. (2013), Dynamics of Relations between different Actors when Building Peace: The Role of Hybridity and Culture, Berghof Foundation Operations.

Hoffman F. G. (2007), Conflict in the 21st Century: The Rise of Hybrid Wars, Potomac Institute for Policy Studies, Arlington, http://www.potomacinstitute.org/images/stories/publications/ potomac_hybridwar_0108.pdf, 26.10.2016.

Home Office (2006), Borders, Immigration and Identity Action Plan: Rusing the national identity scheme to strengthen our borders and enforce compliance within the UK, HMSO, December, London.

Lapid Y. (2001), Identities, borders, orders: Nudging international relations theory in a new direction, w: Identities, Borders, Orders, red. M. Albert, D. Jacobson, Y. Lapid, Minneapolis.

Moraczewska A. (2008a), Transformacja funkcji granic Polski, Lublin.

Moraczewska A. (2008b), Znaczenie granicy państwowej w porzqdku późnowestfalskim - transformacja czy status quo ante, w: Późnowestfalski ład międzynarodowy, red. M. Pietraś, K. Marzęda, Lublin.

Moraczewska A. (2015), Adaptacja funkcjonowania strefy Schengen wobec dynamiki środowiska międzynarodowego, w: Unia Europejska wobec wyzwań przyszłości. Aspekty społeczne, gospodarcze i środowiskowe, red. E. Małuszyńska, P. Idczak, G. Mazur, Poznań.

Nederveen-Pieterze J. (1994), Globalisation as Hybridisation, „International Sociology”, ss. 161-184.

Pietraś Z. J. (1990), Adaptacyjność spenetrowanych systemów politycznych, Lublin.

Rozporządzenie Parlamentu Europejskiego i Rady (UE) 2016/1624 z 14 września 2016 r. w sprawie Europejskiej Straży Granicznej i Przybrzeżnej, Dz. U. L251 z 16.9.2016.

Rozporządzenie Parlamentu Europejskiego i Rady (UE) 2016/399 z dnia 9 marca 2016 r. w sprawie unijnego kodeksu zasad regulujacych przeptyw osób przez granice (kodeks graniczny Schengen; Dz. U. L 77 z 23.3.2016.

Rozporządzenie Parlamentu Europejskiego i Rady (WE) nr 562/2006 z dnia 15 marca 2006 r. ustanawiajace wspólnotowy kodeks zasad regulujacych przepływ osób przez granice (kodeks graniczny Schengen), Dz. U. L 105 z 13.04.2006.

Siehr A. (2012), Odkrycie wymiaru przestrzennego w polityce europejskiej, „Nowa Europa” nr 2(13), ss. $142-185$.

Słownik języka polskiego - wersja internetowa, http//sjk.pl/chimera, 22.10.2016.

Traktat o Unii Europejskiej i Traktat o funkcjonowaniu Unii Europejskiej - tekst skonsolidowany, Tytut V TFUE (art. 67-89), Dz. U. C 115 z 9.05.2008.

Waltz K. N. (1979), Theory of International Politics, New York

Vaughan-Williams N. (2012), Border Politics. The Limits of Sovereign Power, Edinburgh.

\section{Streszczenie}

Granica jest kluczowym elementem strategii bezpieczeństwa państwa. UE jako podmiot stosunków międzynarodowych przyczyniła się do jakościowej zmiany istoty granic państwowych. Z jednej strony uwzględnia jej funkcję porządkowania dwóch systemów prawnych na poziomie suwerennych państw, a z drugiej „odrywa” granicę od jej jedynie terytorialnego wymiaru, wyznaczającego zakres owej suwerenności, i umieszcza w przestrzeni, gdzie zachodzi synteza interakcji między różnymi podmiotami stosunków międzynarodowych. Idea funkcjonowania granic Unii Europejskiej wpasowuje się w koncepcję hybrydowej struktury samej Unii. Jest unikalnym bytem w kategorii prawa międzynarodowego, nie mając swojego odpowiednika w żadnej innej aktualnej strukturze integracyjnej. Granice UE są hybrydową formą tradycyjnie rozumianego określenia granicy w odniesieniu do państwa, cechuje je nie- 
jednorodność i zmienność funkcjonalna oraz wysoka wrażliwość na turbulencje środowiska międzynarodowego.

Słowa kluczowe: Unia Europejska, granice, hybrydowość granic

\section{Hybridity of Borders of the European Union in International Environment}

\section{Summary}

The border is a key element in the security strategy of the state. The EU as an entity of international relations has contributed to a qualitative change in the essence of state borders. On the one hand, it takes into account the role of border in organizing the legal systems of sovereign states, and on the other "detaches" borders from their territorial dimension. The idea of borders within the European Union matches with the concept of the hybrid structure of the EU itself. They are a unique phenomenon in international law with no equivalent in any other current integrating structure. EU borders are a hybrid form of their traditional perception form the state perspective and they are characterized by heterogeneity, variability and high sensitivity to the turbulence of the international environment.

Key words: European Union, borders, hybridity of borders 